\title{
CONSEQUENCES OF FISCAL DEFICIT AND PUBLIC DEBT IN FINANCING THE PUBLIC SECTOR
}

\author{
Aleksandra Tešić1, Dragan Ilić², Anastazija Tanja Đelić ${ }^{3}$
}

\begin{abstract}
Summary
The aim of this paper is to highlight the important issues of the budget deficit and public debt and their impact on economic growth. This paper considers the twin deficit hypothesis, which argues that there is a strong correlation between the current account deficit for an economy and government budget deficits. In the last ten years, Serbia is faced with a situation of simultaneous fiscal deficit and current account deficit. However, the growth of gross domestic product and the maturity of the debt obligation indicate that the debt burden increases, the weak development of the economy and the debt, and the power of the state and threatened to open debt crisis, the emergence of foreign insolvency. To explore the effects of budget deficits and public debt in macroeconomic relations and aggregates applied the methods of descriptive statistics, and used the official data of the relevant national and international institutions. The main results of the analysis indicate a crisis of public finances, which are accumulated for many years, with a growing budget deficit and the dominant external financing of the budget deficit.
\end{abstract}

Key words: budget deficit, investment, public debt, spending, economic growth.

JEL: $E 62, H 63$

\section{Introduction}

According to the conventional definition, fiscal deficit is the difference between total revenue and total expenditure of the state, created over a period of time, usually for one year. But, so defined fiscal deficit is not reliable measure and for the purposes of deficit analysis and its impact on other macroeconomic values necessary to accurately determine the contents of this term. This is so because the amount and significance of fiscal deficit

1 Associate Professor, Business Academy University, Faculty of Economics and Engineering Management, Cvećarska 2, 21000 Novi Sad, Phone: +381 692000 954, E-mail: prof.aleksandra.tesic@gmail.com

2 Assistant Professor, Business Academy University, Faculty of Economics and Engineering Management, Cvećarska 2, 21000 Novi Sad, Phone: +381 602400 935, E-mail: prof.dragan.ilic@gmail.com

3 Assistant Professor, Ministary of Finance of Serbia, Kneza Miloša 20, 11000 Belgrade, Phone: +381 63295 656, E-mail: tanja.djelic@gmail.com

EP 2014 (61) 1 (177-194) 
changes depending on the scope of the state: the central government, consolidated central government, which apart from the central government includes and non-budgetary funds; the consolidated general government, which includes revenues and expenditures of local governments, authorities, public sector whole, which includes the balance of financial transactions of public companies, as well as fiscal transactions of the financial sector (privatization funds and / or development banks). Consequently, the most comprehensive measure of state impact on other sectors and the economy as a whole should include government deficits in its broadest scope. As is known, such a measure is rarely published so typically in the analysis is used deficit of the central, consolidated central or consolidated general government (Davina at al., 2002).

In addition to a measure of the deficit, which is based on the simple difference of income and expenditure, often for a specific purpose are calculated other indicators of deficit, for example, the primary deficit, the operating deficit, structural deficit, cyclically- corrected deficit, current account deficit of the state budget, and the like. For analytical purposes are commonly used: the conventional deficit, primary deficit and the cyclically-corrected deficit, in terms of inflation the real size of these amounts. Cyclically-corrected deficit is applied in the analysis of multipliers based on the traditional IS-LM model. The conventional deficit as partly endogenous, has no a multiplier effect, because it is the result of increased transfers to the unemployed (as opposed to the deficit, which is a result of growth in public investment), and as such is already incorporated in the multiplier (Tobin, 2001).

Since the state budget deficit is a residual size, it is clear that there are considerable difficulties in assessing its impact on the economy as a whole, as well as on some macroeconomic aggregates. This follows from the fact that does matter how the deficit is caused, whether as a: result of the tax cuts; a result of growth in government spending; and in particular from the fact that the impact of the deficit varies depending on which taxes and expenditures are matter of change. From the foregoing, it may be concluded that the impact of the deficit on the economy should be considered in the context of the specific fiscal policies and measures on which it rests.

One of the important conclusions from a number of empirically analyses is that there is a difference in the effects of permanent and temporary deficits. While, temporary deficits can have the stabilization effect, the impact of permanent deficit depends on the way of deficit financing: issuing money and/or borrowing. The public debt does not increase when the deficit is financed by issuing money, and has no effects on the change of level of indebtedness, unless the debt is denominated in local currency and when it is not indexed. This means that public debt is the result of permanent deficits that are financed by borrowing (at home or abroad). From the results shown follows that the deficit of the public debt level changes between the two years (if not financed by creating money) and their effects on the economy are consistent in cases of permanent fiscal deficit and debt financing. 


\section{The consequences of fiscal deficits and public debt}

There are three theories about the effects of budget deficits and public debt: Keynesian, neoclassical and Rikardian School. Their common characteristic is that they mainly discuss the situation of deficit occurrence due to the reduction in tax revenue, and not due to an increase in government spending (although the Keynesian school in the original version sees the effects of the increase in public spending to changes in employment and output, and later the effects of a decrease in tax revenues). In general, differences in attitudes about the deficit and public debt are resulting from different choices of assumptions underlying the models of different schools (Tempelman, 2005).

Pursuant to the doctrine of classical economics, the deficit and public debt were a justifiable only in exceptional circumstances and for short-term needs of public spending, while their permanent existence justified only in the case of financing of productive capital projects whose rate of return higher than the rate of interest on borrowings. According to the belief of the classical economists, there is no significant difference between borrowing by state and borrowing by private individuals. Each type of debt is for the harmonizing flow of income and expenses over time.

The neoclassical school is based on the assumption that people have a limited lifetime and that generations overlap, and that in all periods there is a balance on the market. Budget deficits increase overall love spending by shifting taxes on the next generation. If economic resources are fully utilized, increased consumption necessarily implies a reduced savings. The situation in the capital market is changing, and the interest rate must rise as the market would come back into balance. Permanent deficits in this way "crowd out" private accumulation of capital, which has devastating consequences for economic growth (Bernheim, 1989).

The Keynesian school proceeds chronologically to neoclassical, and is based on the premise that timely deficits have favourable effects on welfare. However, there are situations in which stimulation of aggregate demand caused by a deficit has adverse effects. Such example is the situation of full employment and a fixed supply of money, when increased money demand leads to rising of interest rates and falling investment. Accordingly, set out, Keynesian school leaves the possibility that the deficit has positive or negative effects, depending on the state of the economy. This means that Keynesian theory is unable to provide universal recommendations to politicians, and that they themselves should identify what state the economy is, in order to comply with this could take appropriate measures (Radcliffe, 2009).

Rikardian School assumes that successive generations are connected with selfless and voluntary transfer of resources. This means that the consumption is function of resource of taxpayers and their descendants. Deficits only delay the payment of taxes, leaving it to future generations, while the discounted present value of taxes and government spending is equal, which means that the deficit of previous generations' leaves resources unchanged. Consumption, as a function of resource generation, does not change under the influence of tax changes. In other words, the fiscal deficit policies have no impact on the real economy size. 
Rikardian School begins from the hypothesis of neutrality of debt, and is based on the following, very restrictive assumptions: 1) the time horizon of the citizens / taxpayers is infinite, 2) differences in tax burdens motivate citizens to intergenerational transfers based on altruism, 3) consumers are rational and farsighted, 4) capital markets are either perfect, or they have specific error, 5) taxes are lump sum, 6) the use of deficit cannot create value and 7) public spending cannot be indefinitely financed by borrowing. Given that these assumptions do not correspond to reality, and that the hypothesis of neutrality of debt cannot be sustained if it leaves any of these assumptions, it is considered that rikardian direction cannot give good instructions for conducting specific budget policy (Arrau, 1990).

The neoclassical and Keynesian paradigm can be complimented quite well, especially when it is seen as two different aspects of the analysis of fiscal policy. Decomposition of deficit to its permanent and temporary component can be concluded that the neoclassical analysis examines the effects of permanent deficits, while Keynesian recognizes the impact of temporary deficit, which should to be taken to stabilize cyclical fluctuations around the equilibrium with full employment. In other words, the neoclassic considers lower debt more favourable from the standpoint of the average national savings, but allows interim government deficits, which are used to stabilize the economy close to equilibrium (Bernheim, 1989).

From the theoretical point of view, it seems that the neoclassical analysis is based on the least restrictive assumptions and that describes most realistic reality. Considering the impact of the deficit on the economy, neo-classicists believe that the key question is whether the deficit is temporary or permanent. Specifically, if consumers focus on their life spending, reducing the deficit caused by the increase of the tax burden, according to neo-classicists, will cause a greater drop in demand if consumers believe that the reduction is permanent. In this case, the government attempt to achieve a balance with greater savings could reduce demand so that it would cause a recession. On the other hand, neo-classicists believe that impact on lasting deficit of any presign on the economy depends on the level of economic development and economic objectives. That is, if private savings are insufficient to achieve the desired level of capital accumulation, then the state must pursue a permanent surplus.

The main drawback of these theories is that those in the study of the effects of the deficit and public debt on economic activity largely ignored: (a) the method of financing the deficit (debt issue or monetary financing), (b) the cause of deficits (increase in government spending or lower tax revenues), (c) the structure of tax revenue and government spending; (d) the period within which to conduct deficient financing (except neoclassical distinguishing between permanent and temporary deficits), (e) whether exogenous policy anticipated or non-anticipated. From this point of view, some recent considering of the impact of deficits on economic activity starts from the fact that, in order to assess the impact of fiscal policy on aggregate demand, it is necessary to develop a model of the economy, and specify the key policies (in relation to which a policy can be expansionary or call restrictive), (Buiter, 1986). 


\section{Fiscal spending and economic growth}

In discussing the issue of sustainable public debt, it is necessary to focus the analysis of the fiscal sector, given that this is the most important concern of economic policy. A large national debt, when financed from domestic sources, can lead to an increase in taxes, or owing to increase of interest rates to the crowding-out in the private sector. On the other hand, if it is financed from foreign sources, a large national debt may require drastic macroeconomic adjustment, which would lead to instability.

Trend of public expenditure, both overall, and in structure, generally is compared with the movement of gross domestic product and the ratio of these two macro aggregates. From the share of public revenues and expenditures of gross domestic product is statistically considered gross domestic product burden by operations of public consumption needs and pressure in this form of consumption in total consumption, and market prices. That is to look at how much country burdens by its "non-productive" consumption its gross domestic product.

Today, most of the authors most commonly use indicator of the evolution of the debt to GDP, especially after the advent of Blanchard (1990), but also because of the many difficulties in the use of other indicators. This indicator measures the level of debt in relation to the economic activity of the country, which implicitly assumes that for financing debt burden are available all the resources of GDP. However, this may not always be true. On the other hand, this is regarded as the most important indicator for measuring the level of debt, because it indicates the degree of solvency of the government (Blanchard, 1990). At the same time, it is possible to examine the degree of burden of the business sector and the household sector by the volume of public spending.

In this context, a critique of "excessive" government spending and higher tax procedures is the critique of state intervention in the economy, choking of economic activity, but also a source of instability (and the contemporary financial crisis). Data presented in Table 1 illustrate the burden of GDP by expense on the basis of public expenditures of Republic of Serbia.

Table 1. Burden of GDP by public expenditure and revenues (in billion RSD), the consolidated public sector balance

\begin{tabular}{|c|c|c|c|c|c|c|c|}
\hline \multirow{2}{*}{ Year } & \multirow{2}{*}{ GDP } & \multirow{2}{*}{$\begin{array}{c}\text { Public } \\
\text { expenditure }\end{array}$} & \multirow{2}{*}{$\begin{array}{c}\text { Public } \\
\text { revenues }\end{array}$} & \multirow{2}{*}{$\begin{array}{l}\text { Budget } \\
\text { Deficit }\end{array}$} & \multicolumn{3}{|c|}{ Share of GDP } \\
\hline & & & & & Exp. & Rev. & Deficit \\
\hline 2005 & $1.883,5$ & 706,8 & 724,5 & $+17,6$ & 37,5 & 38,4 & $+0,9$ \\
\hline 2006 & $1.962,1$ & 899,3 & 867,7 & $-31,6$ & 45,8 & 44,2 & $-1,6$ \\
\hline 2007 & $2.276,9$ & $1.046,8$ & $1.002,0$ & $-44,8$ & 45,9 & 42,0 & $-3,0$ \\
\hline 2008 & $2.661,4$ & $1.213,9$ & $1.134,4$ & $-70,5$ & 45,6 & 42,9 & $-2,7$ \\
\hline 2009 & $2.713,2$ & $1.267,9$ & $1.146,5$ & $-121,4$ & 46,7 & 42,2 & $-4,5$ \\
\hline
\end{tabular}




\begin{tabular}{|c|c|c|c|c|c|c|c|}
\hline \multirow{2}{*}{ Year } & \multirow{2}{*}{ GDP } & \multirow{2}{*}{$\begin{array}{c}\text { Public } \\
\text { expenditure }\end{array}$} & Public & \multirow{2}{*}{$\begin{array}{c}\text { Budget } \\
\text { revenues }\end{array}$} & Deficit & \multicolumn{3}{|c|}{ Share of GDP } \\
\hline 2010 & $2.986,8$ & $1.359,8$ & $1.225,2$ & $-134,6$ & 45,5 & 41,0 & $-4,5$ \\
\hline 2011 & $3.293,3$ & $1.460,9$ & $1.302,5$ & $-158,4$ & 44,8 & 39,5 & $-5,3$ \\
\hline 2012 & $3.267,1$ & $1.622,8$ & $1.405,4$ & $-217,4$ & 49.7 & 43,0 & $-6,7$ \\
\hline
\end{tabular}

Source: Bulletin of the Public Finance, the Ministry of Public Finance of Republic of Serbia, no. 12, 2011, Tables 1 and 2, and for 2012, the same source in October 2012, Table 1 - assessment.

In the crisis period (2008-2012 years), it is evident the reduction of public revenue and expenditure in gross domestic product, but the decline in the share of public revenues increasing, leading to an increase in the budget deficit. The exception is 2012, which indicates a deepening of the crisis indebtedness.

Data presented in Table 2 indicate excessive public spending and spending and the forms that have become generators of development problems and instability of the Serbian economy.

Table 2. Gross domestic product and charged with public consumption (in \%)

\begin{tabular}{|l|c|c|c|c|c|c|c|c|}
\hline \multicolumn{1}{|c|}{ Element } & $\mathbf{2 0 0 5}$ & $\mathbf{2 0 0 6}$ & $\mathbf{2 0 0 7}$ & $\mathbf{2 0 0 8}$ & $\mathbf{2 0 0 9}$ & $\mathbf{2 0 1 0}$ & $\mathbf{2 0 1 1}$ & $\mathbf{2 0 1 2}$ \\
\hline Real GDP growth & 5,2 & 3,6 & 5,4 & 3,8 & $-3,5$ & 1,0 & 1,6 & $-2,0$ \\
\hline Nominal GDP growth & 21,9 & 16,6 & 16,0 & 16,8 & 1,9 & 10,0 & 10,2 & 1,0 \\
\hline $\begin{array}{l}\text { The increase in } \\
\text { consolidated revenue }\end{array}$ & 10,8 & 10,5 & 17,4 & 12,3 & 2,5 & 6,9 & 6,3 & 5,9 \\
\hline $\begin{array}{l}\text { The increase in } \\
\text { consolidated public } \\
\text { expense }\end{array}$ & 12,3 & 23,7 & 16,4 & 16,0 & 4,4 & 7,2 & 7,4 & 11,6 \\
\hline $\begin{array}{l}\text { The share of public } \\
\text { expenditure in GDP }\end{array}$ & 37,5 & 45,8 & 46,0 & 45,6 & 46,7 & 45,5 & 44,8 & 49,7 \\
\hline $\begin{array}{l}\text { The share of revenue in } \\
\text { GDP }\end{array}$ & 38,4 & 43,6 & 44,3 & 41,2 & 42,2 & 41,0 & 39,5 & 43,0 \\
\hline $\begin{array}{l}\text { Budget deficit or surplus } \\
\text { - classic, the primary }\end{array}$ & $+17,6$ & $-31,6$ & $-54,7$ & $-70,5$ & $-125,4$ & $-134,6$ & $-158,4$ & $-217,4$ \\
\hline $\begin{array}{l}\text { Share of the deficit to } \\
\text { GDP (official) }\end{array}$ & $+0,9$ & $-1,6$ & $-3,0$ & $-2,7$ & $-4,5$ & $-4,5$ & $-5,3$ & $-6,7$ \\
\hline
\end{tabular}

Source: Serbian Ministry of Finance, Public Finance Bulletin, December 2008 and 2011, October 2012.

The following very important conclusion that follows from the analysis of the data table above is the fact that the budget expenditure in the years of the crisis increases slower than nominal GDP growth, same for the consolidated public revenues. However, the share of public expenditure and revenue to GDP shows some instability, because after three years of 
lowing record growth of these aggregates.

Gross product burden on the Serbian economy in comparison to other EU countries is not greater, on the contrary, is lower. However, the main problem is slower economic growth, where the effects of inflation are not reflected in the public sector, given that the real annual increase in expenses and revenues below nominal GDP growth (Nikolić, 2011). Classic (primary) deficit in the years of the crisis holds at the level of 4.3 to $4.5 \%$ of GDP, although in total weight year by year increases, so that the problem arose from its funding. On this conclusion point out data given in Table 3 .

Data Table 2 refers to the consolidated budget, however, when you observe these relationships in the Republican budget (budget classic country), which is most often said in public hearings, the picture changes significantly.

Table 3. Revenue, expenditure and deficit of Serbia (changes in \%)

\begin{tabular}{|l|c|c|c|c|c|c|c|}
\hline \multicolumn{1}{|c|}{ Element } & $\mathbf{2 0 0 5}$ & $\mathbf{2 0 0 6}$ & $\mathbf{2 0 0 7}$ & $\mathbf{2 0 0 8}$ & $\mathbf{2 0 0 9}$ & $\mathbf{2 0 1 0}$ & $\mathbf{2 0 1 1}$ \\
\hline Nominal GDP growth & 21,9 & 16,5 & 16,0 & 16,8 & 1,9 & 10,0 & 10,1 \\
\hline Annual revenue growth budget & 10,8 & 10,5 & 17,3 & 12,3 & 0,7 & 8,6 & 4,6 \\
\hline Annual expenditure growth & 12,3 & 20,7 & 16,6 & 13,6 & 6,3 & 9,8 & 6,9 \\
\hline $\begin{array}{l}\text { The share of expenditure of the budget } \\
\text { to GDP }\end{array}$ & 37,0 & 27,0 & 27,1 & 26,3 & 27,5 & 27,4 & 26,6 \\
\hline $\begin{array}{l}\text { The share of total revenues of the budget } \\
\text { to GDP }\end{array}$ & 37,7 & 25,1 & 25,4 & 24,4 & 24,1 & 23,8 & 22,6 \\
\hline $\begin{array}{l}\text { Deficit of the Republic budget } \\
\text { (billions of RSD) }\end{array}$ & $+8,2$ & $-35,6$ & $-38,1$ & $-50,8$ & $-90,5$ & $-108,0$ & $-132,5$ \\
\hline Share of the deficit to GDP & $+0,8$ & $-1,8$ & $-1,7$ & $-1,9$ & $-3,4$ & $-3,6$ & $-4,0$ \\
\hline
\end{tabular}

Source: Serbian Ministry of Finance, Public Finance Bulletin, October 2012, http://mfp.gov.rs/ UserFiles/File/bilten\%20javne20finansije/bilten\%\%20-\%2098\%20-\%20for\%20SRP20web\%.pdf

Classical state budget, with all the criticism that has lately been referred to government spending and highlighting the need for reform of the public sector (public finance), cannot be characterized as a large fiscal burden. The problem is extremely weak real economic growth, low tax base and little public revenue to finance public expenditure of the budget (Đurić at al., 2011).

Sustainability problem can be formulated as follows: the budget deficit leads to an increase of the public debt that will have to be serviced in the future. If interest rates on public debt exceed the growth rate of the economy, the debt is set up dynamically, so that the ratio of public debt to GDP ratio deteriorates. It is clear that this can become unsustainable and require corrective action (Ball, Mankiw, 1995). 
According to the definition, the public debt is sustainable when its level may remain unchanged for long, and it does not lead to the need to change fiscal policy (Brümmerhoff, 2007). In this sense, Serbia's debt is unsustainable, and fiscal reforms do not contribute to reducing the budget deficit. From this point of view, it is not an appropriate question whether sustainability is achieved, rather it is important the question whether government policies are leading to sustainability.

The dynamics of the annual increase in public revenue and expenditure are less than the annual growth of nominal (infantry) gross domestic product. This tendency is especially pronounced in the new age of crisis, with the increase in revenue is less than the increase in public expenditure. This led to accumulation of budget deficits, lowering the share of public revenue and expenditure in gross domestic product (at $37.7 \%$ of revenue to $22.6 \%$, and expenditures from $37 \%$ to $26.6 \%$ ).

The structure and dynamics of the expenditure budget show some problematic trends:

1) Revenue collection efficiency decreases considerably;

2) Public expenditure autonomously behaves in relation to gross domestic product, which leads to the explosive expansion of additional financing of budget expenditures;

3) Budgetary control is significantly limited, and thus the efficiency of funds.

\section{Foreign debt, economic growth and the debt burden}

Indebtedness is one of the most serious financial-monetary, balance of payments, developmental, social and political problems of developing countries.

Foreign indebtedness of Serbia with a growing budget deficit and balance of payments and balance of trade becomes major problem of economic development. However, the problem of the foreign debt has another, much more serious side, compared to the very level of public debt and its ratio to gross domestic product. Officially it is stated that it is "relatively low public debt and liveable." But this is only part of the total debt related to the public sector (government). Serbia's total public debt is much higher, and a heavy burden of the national economy, not only GDP but also the development of the economy. Furthermore, we point out that the ratio of debt to gross domestic product almost does not matter when assessing the actual indebtedness of the economy and the debt burden. There are many more important indicators of debt burden indicators and debt levels, and indications of a possible debt crisis.

The optimum amount and structure of foreign debt is the result of the optimal ratio of national production and consumption, as well as other basic macro aggregates of the economy. Namely, the foreign debt and behaviour indebtedness of the resultant is dynamics, quality, structure and stability of the national economy. From this point of view, the size and structure of foreign debt to the additional accumulation from abroad is seen as an active and an additional factor of economic development, not only to temporarily fill the gap between domestic savings and investment, but also leads 
to efficiency incentives and social profitability of investments, the use of domestic investments, especially in the phases when the cost of capital in the global market is extremely high (Bernheim, 1989).

When analysing the impact of public debt on economic growth, it is common to consider the relationship of gross domestic product and foreign debt, as well as their yearly schedule. The importance of considering the level of foreign debt and annual debt burden on that basis, may be called the autonomous phase of growth which is indisputable. In this sense, we present data on the amount of foreign debt, economic growth and the debt burden of the Serbian economy (Table 4).

Table 4. Foreign debt, economic growth and the debt burden (in billions of EUR)

\begin{tabular}{|c|c|c|c|c|c|}
\hline Year & GDP & Foreign debt & $\begin{array}{c}\text { Annual GDP } \\
\text { growth (in \%) }\end{array}$ & $\begin{array}{c}\text { Debt increase } \\
\text { (in \%) }\end{array}$ & Debt/GDP \\
\hline 2002 & 16.028 & 9.402 & 4,2 & 2,9 & 58,8 \\
\hline 2003 & 17.306 & 9.678 & 2,5 & 2,2 & 55,9 \\
\hline 2004 & 19.026 & 9.466 & 8,4 & $-2,2$ & 55,9 \\
\hline 2005 & 20.306 & 12.196 & 6,2 & 28,8 & 60,1 \\
\hline 2006 & 23.305 & 14.182 & 5,3 & 16,2 & 60,9 \\
\hline 2007 & 28.468 & 17.139 & 7,2 & 20,8 & 60,2 \\
\hline 2008 & 32.668 & 21.088 & 5,4 & 23,0 & 64,6 \\
\hline 2009 & 28.883 & 22.487 & $-3,5$ & 7,0 & 77,9 \\
\hline 2010 & 28.984 & 23.786 & 1,0 & 5,8 & 82,1 \\
\hline 2011 & 31.140 & 24.825 & 1,9 & 4,4 & 79,7 \\
\hline 2012 & 30.074 & 25.721 & $-3,4$ & 3,6 & 85,6 \\
\hline
\end{tabular}

Source: NBS, Inflation Report, February 2013, table A and B.

During the period of the explosive spread of foreign debt (2005-2012) average rate of growth of debt is as high as $15 \%$, while the average rate of economic growth around $3 \%$. Consequently, the growth of debt at this stage is about five times faster than the growth of national wealth. Debt-to-GDP in the last five years is constantly growing in 2012 amounted to $85.6 \%$.

The severity of these problems can be realistically seen from Table 5 data on the behaviour of foreign debt and GDP calculated at the real exchange rate (the equilibrium exchange rate that eliminates the difference in inflation rates in our economy in the developed EU countries, adjusted for rate changes undergone during the course - or devaluation revaluation of course). The data show a more realistic picture compared with the movements of nominal gross domestic product in the euro translated at average exchange rate of the current. 
Table 5. The share of foreign debt to gross domestic product - the current and equilibrium (real) exchange rate (in millions of EUR)

\begin{tabular}{|c|c|c|c|c|c|c|c|}
\hline Year & $\begin{array}{c}\text { Official } \\
\text { course } \\
\text { Euro }\end{array}$ & $\begin{array}{c}\text { equilibrium } \\
\text { course } \\
\text { Euro }\end{array}$ & $\begin{array}{c}\text { external } \\
\text { debt }\end{array}$ & $\begin{array}{c}\text { Official } \\
\text { GDP }\end{array}$ & $\begin{array}{c}\text { GDP per } \\
\text { equilibrium. } \\
\text { course }\end{array}$ & \multicolumn{2}{|c|}{ Debt-in GDP } \\
\hline 2005 & 85,5 & 114,2 & 12.196 & 20,306 & 14.767 & 60,1 & 82,5 \\
\hline 2006 & 79,0 & 130,6 & 14.182 & 23.305 & 14.987 & 60,9 & 95.4 \\
\hline 2007 & 79,2 & 141,0 & 17.139 & 28.468 & 16.148 & 60,2 & 106,1 \\
\hline 2008 & 88,6 & 143,0 & 21.088 & 32.668 & 18.611 & 64,6 & 113,3 \\
\hline 2009 & 95,9 & 138,0 & 22.487 & 28.883 & 19.661 & 82,1 & 106,6 \\
\hline 2010 & 105,5 & 134,3 & 23.766 & 28.984 & 22.288 & 82,1 & 106,6 \\
\hline 2011 & 104,6 & 142,3 & 24.825 & 31.140 & 23.377 & 79,7 & 110,4 \\
\hline 2012 & 113,1 & 150,4 & 25.721 & 30.074 & 21.723 & 85,6 & 118,4 \\
\hline
\end{tabular}

Source: as for the previous table - by calculation.

The data suggested that the highly overvalued exchange rate in a number of years, leading to unrealistically high GDP expressed in euros, since nominal GDP converted into undervalued euro, leading to the "inflated" inflate GDP and decreasing share of foreign debt and liabilities of debt to GDP. This phenomenon can be partially explained by the so-called BalassaSamuelson effect this. Higher inflation in developing countries means higher nominal GDP, which contributes to the reduction in the public debt / GDP (Balassa, Samuelson, 1964). The practice of presenting the budget deficit and public debt of Serbia confirms this conclusion.

Level Indicator and debt burden, which is defined by the ratio of debt to gross domestic product is not enough, because it does not fully reflect the level of indebtedness of any state. The problem is not the level of debt and debt-to-GDP, but the amount of annual debt obligations (interest and repayments) and the growth of gross domestic product, and the structure and terms of debt and the effects of their use. It is usually quite unrealistic and distorted purely statistical relationship, especially because of the unreality of expressing Gross Domestic Product. If you take only the debt of the public sector (the state of Serbia), which is mostly done, then the ratio is about $60 \%$, and it is claimed that Serbia is one less charge in comparison with other European countries, and in this way, one gets the wrong conclusion the fulfilment of the convergence of the Maastricht criteria key.

To refine the overall indebtedness of the country, as well as the necessity arises the need to consider the following important relations. 1) Short-term and long-term debt, 2) of the maturities of debt and GDP growth, 3) the amount of interest as fixed obligations; 4) systems using debt (productive, unproductive) and the efficiency of the economy and the social product, and 5) the relationship due debts of debt and GDP growth, 6) height of the trade deficit and balance of payments; 7) the dynamics of economic growth and the growth rate of foreign debt, and 8) the ability of the debt write-offs, and 9) the amount and structure of foreign 
exchange reserves, 10) readiness of the international financial institutions (IMF, world Bank, etc.) to ease the burden of debts, 11) trends in the global capital markets (interest rates, terms, availability) and others (Hubbard, 2011). In this sense, the model of the bank of England is quite instructive (Bank of England) which simulates the behaviour of 17 endogenous and 17 exogenous variables included in the 18 equation, for optimum results in the movement of GDP (Arestis, Sawyer, 2004).

It is obvious that this is a series of indicators that each government has to follow to guide policy, optimal external debt and international liquidity, in order to prevent entry into the debt crisis, and international insolvency. From this point of view, the ratio of debt to gross domestic product does not mean a lot as an indicator of indebtedness, but annual economic growth and rising debt and liabilities of the debt during the year, but show that you are weak or strong general development of the economy or the power of moving in the direction of over-indebtedness and the emergence of so-called ,noose of debt" (Arestis, Sawyer, 2004).

\section{The structure of foreign debt by sector}

The structure of foreign debt holders is very important, especially in terms of their conditions of use, routing, and effects that give the local economy. The debt of the state (public sector) in the last years is constantly lowering that, while the debt of banks and the economy (which is due to high foreign exchange reserve banks borrow directly abroad) has been increasing. Not foreign debts of banks and companies only their concern, but it is a part of the total debt obligation from which the following payments and interest rates, which ultimately pays the total economy (Arestis, Sawyer, 2004).

Table 6. The structure of foreign debt by sector (in millions of EUR)

\begin{tabular}{|c|c|c|c|c|c|}
\hline Element & $\mathbf{2 0 0 1}$ & Structure & $\mathbf{2 0 1 2}$ & Structure & Change 2001-2012. \\
\hline Public sector & 10.256 & 93,5 & 10.900 & 42,4 & +644 \\
\hline (in that NBS) & 309 & & 1.596 & & 1.287 \\
\hline SPU & - & & 453 & & 453 \\
\hline Short-term & 150 & & - & & -150 \\
\hline Enterprise & 607 & 5,5 & 9.930 & 38,6 & +9.323 \\
\hline Long-term & 38 & & 9.832 & & +9.794 \\
\hline Short-term & 569 & & 98 & & -471 \\
\hline Banking sector & 105 & 1,0 & 4.891 & 19,0 & +4.786 \\
\hline Element & $\mathbf{2 0 0 1}$ & Structure & $\mathbf{2 0 1 2}$ & Structure & Change 2001-2012. \\
\hline Long-term 10 & 10 & & 4.277 & & +4.267 \\
\hline Short-term & 95 & & 614 & & +519 \\
\hline Total debt & 10.968 & 100 & 25.721 & 100 & +14.753 \\
\hline
\end{tabular}

Source: Bulletin of Public Finance, December 2011, p. 21, Table 8, for 2012 according to the end of October. 
Table 7. The dynamics of foreign debt holders (sectors), (in million EUR)

\begin{tabular}{|c|c|c|c|c|c|c|c|}
\hline \multirow{2}{*}{ Year } & \multirow{2}{*}{$\begin{array}{c}\text { Public } \\
\text { sector }\end{array}$} & \multirow{2}{*}{$\begin{array}{c}\text { Participation } \\
\text { in total (\%) }\end{array}$} & \multicolumn{2}{|c|}{ Private sector } & \multirow{2}{*}{ Total } & Participation & $\begin{array}{c}\text { Total } \\
\text { external debt }\end{array}$ \\
& & Banks & Economy & & & 6,5 & 10.968 \\
\hline 2001 & 10.256 & 93,5 & 105 & 607 & 712 & 35,3 & 12.196 \\
\hline 2005 & 7.892 & 64,7 & 1.754 & 2.550 & 4.304 & 53,5 & 14.182 \\
\hline 2007 & 6.592 & 46,5 & 3.477 & 4.113 & 7.590 & 63,3 & 17.139 \\
\hline 2008 & 6.285 & 36,7 & 3.606 & 7.248 & 10.854 & 69,1 & 21.088 \\
\hline 2009 & 7.764 & 34,5 & 4.310 & 10.414 & 14.724 & 65,5 & 22.487 \\
\hline 2010 & 9.076 & 38,2 & 5.093 & 9.617 & 14.710 & 61,8 & 23.788 \\
\hline 2011 & 10.607 & 44,5 & 4.291 & 9.586 & 13.877 & 55,5 & 24.825 \\
\hline 2012 & 10.900 & 42,4 & 4.891 & 9.930 & 14.821 & 57,6 & 25.721 \\
\hline
\end{tabular}

Source: Bulletin of Public Finance, no. 12/2011, p. 21 and October 2012.

The explosive growth of foreign debt occurs in the private sector during this period increased by 712 million euros to 14.8 billion, or $6.5 \%$ of the total to nearly $60 \%$ (Table 6 and 7 ). Commercial banks are due to high foreign currency reserves (which ranged between $45 \%$ and $60 \%$ ) were referred to the company direct foreign borrowing by banks and other financial institutions. In this way increased the outflow of interest and repayment.

Given the fact that the banks control almost $90 \%$ of the assets of the Serbian banking system, realistically assumed that their banks 'mothers' support (or guarantee) their borrowings. In addition, it should be noted that private sector borrowing abroad may be based on erroneous beliefs about the relatively stable exchange rate, which can deepen the financial crisis. One gets the impression that this kind of borrowing, for now, is not significant.

The structure used loans enterprise sector is very unfavourable and cannot be linked to a greater impact on the acceleration of economic growth. For financial services related 1.9 billion euros in real estate activities and renting 2.1 billion and 1.7 billion in trade. Manufacturing uses only 935 million (that production of food and drinks almost half).

In terms of the amount of the effective interest rate on foreign debt should be noted that the weighted average interest rate on total debt is $5.1 \%$, the debt of the public sector $4.8 \%$ and $5.2 \%$ of the banking sector and enterprise debt $5.4 \%$. The problem is that the share of loans with variable interest rate is extremely high, and thus the interest rate risks. For those of total debt is $76 \%$, and $85 \%$ of the banking sector and $88 \%$ of companies, leasing companies, $98 \%$ and $48 \%$ of the public sector (NBS, 2011 and 2012).

From these relationships arises the problem of defining the strategy for the development and financing, to ensure the payment of debts and obligations secured space for dynamic growth and breaking the "debt blocking" or actual "loop debt". The reasons for this is the fact that 
financial capital, which is the encroachment, other means are not needed to conquer new markets and the economy, but depending on the use and behaviour of the world's financial capital (banking, private, public, or international institutions) (Arestis, Sawyer, 2004).

\section{Effects of increment in gross domestic product and debt growth}

The ratio of debt to gross domestic product, which is often used as an indicator of the debt burden, not a true indicator of external debt. It pertains to a year accrued obligations of foreign debts and annual growth of gross domestic product, because it actually shows that you are creating a loop of debt and whether growing debt burden. This circumstance indicates data for the period 2002-2012 (Table 8).

Table 8. Annual growth in gross domestic product and the annual external debt obligations (in \%)

\begin{tabular}{|c|c|c|c|c|c|c|}
\hline \multirow{2}{*}{ Year } & \multirow{2}{*}{$\begin{array}{c}\text { Growth } \\
\text { GDP }(\%)\end{array}$} & \multirow{2}{*}{$\begin{array}{c}\text { Annual } \\
\text { growth of } \\
\text { foreign debt } \\
(\%)\end{array}$} & \multirow{2}{*}{$\begin{array}{c}\text { Share of } \\
\text { liabilities to } \\
\text { GDP }\end{array}$} & \multicolumn{2}{|c|}{$\begin{array}{c}\text { Annual population } \\
\text { growth (billion EUR) }\end{array}$} & \multirow{2}{*}{$\begin{array}{l}\text { Debt to } \\
\text { GDP }\end{array}$} \\
\hline & & & & GDP & DEBT & \\
\hline 2002 & 4.3 & 2,9 & 1,6 & 3,2 & 0,1 & 67,2 \\
\hline 2003 & 2,5 & 2,9 & 2,5 & 1,4 & $-0,6$ & 62,3 \\
\hline 2004 & 9,3 & $-2,2$ & 5,0 & 1,7 & 0,1 & 54,3 \\
\hline 2005 & 5,4 & 28,8 & 7,6 & 1,3 & 2,7 & 64,8 \\
\hline 2006 & 3,6 & 16,3 & 9,9 & 1,5 & 1,8 & 60,9 \\
\hline 2007 & 5,4 & 20,3 & 10,2 & 3,1 & 2,9 & 64,6 \\
\hline 2008 & 3,8 & 23,0 & 10,5 & 4,2 & 3,9 & 67,6 \\
\hline 2009 & $-3,5$ & 7,0 & 13,6 & $-3,8$ & 1,4 & 77,9 \\
\hline 2010 & 1,0 & 5,8 & 9,4 & 0,1 & 1,3 & 82,1 \\
\hline 2011 & 1,9 & 4,4 & 10,3 & 2,9 & 1,0 & 77,9 \\
\hline $\begin{array}{l}\text { Average } \\
2002-2012\end{array}$ & 3,4 & 9,0 & 8,1 & 15,6 & 14,6 & 68,2 \\
\hline $\begin{array}{c}\text { Years of crisis } \\
\text { 2008-2012 } \\
\text { Average }\end{array}$ & 0,8 & 10,0 & 11,0 & 3,4 & 7,6 & 77,0 \\
\hline
\end{tabular}

Source: NBS, Inflation Report, February 2013, p. 46-47.

Annual growth of debt and the amount of debt maturing obligations indicate that strengthens or weakens the general development of the economy or the power enters the zone of overindebtedness and inability to service foreign debts. The economic growth rate (GDP), which is generated over $70 \%$ of services that are not "export product" in the period 20022012 average is about 3\%, while in the same period, the average annual growth of foreign debt $9 \%$ and share of the debt obligations of $8.1 \%$ (with a constant tendency to increase). 
GDP growth is almost three times slower than the growth of debt and liabilities for the debts. As part of the debt obligation greater than the rate of growth - GDP growth is not sufficient to service the foreign debt. Typical is the period of the crisis (2008) to the end of 2012 year. In this period, the average GDP growth rate falls to $0.8 \%$, the growth of foreign debt was approximately $10 \%$ and debt obligations of $11 \%$. In this period there is a negative GDP growth of 3.0 billion euros, while foreign debt rose by 7.6 billion euros (Table 9 ).

Table 9. A period of crisis and foreign debt liabilities (million EUR)

\begin{tabular}{|c|c|c|c|c|c|c|}
\hline Year & Interest & Payment & Total & $\begin{array}{c}\text { Annual } \\
\text { growth, } \\
\text { GDP }\end{array}$ & $\begin{array}{c}\text { Growth of } \\
\text { GDP minus } \\
\text { liabilities }\end{array}$ & $\begin{array}{c}\text { Annual } \\
\text { growth in } \\
\text { debt }\end{array}$ \\
\hline 2008 & 184,2 & $3.269,0$ & $3.453,2$ & 4.200 & 747 & 3.949 \\
\hline 2009 & 233,4 & $3.080,6$ & $3.314,0$ & -3.785 & -7.099 & 1.319 \\
\hline 2010 & 323,6 & $3.079,5$ & $3.403,1$ & 101 & -3.302 & 1.299 \\
\hline 2011 & 369,1 & $3.693,1$ & $4.062,2$ & 2.857 & -1.205 & 1.039 \\
\hline 2012 & 424,4 & $3.858,0$ & $4.282,4$ & -1.066 & -5.348 & 896 \\
\hline Total & $1.534,7$ & $16.980,2$ & $18.514,9$ & 2.307 & -16.208 & 8.582 \\
\hline
\end{tabular}

Source: Same as for the previous table.

Participation obligations are growing rapidly, so that it can be considered that there were a lot of breaks. Obviously, the external debt "replaced" means usually large and inefficient privatization. Sell off the nation's wealth has replaced the large debt and external debt. Of course, this leads to the large outflow of national savings (accumulation) abroad.

Table 10. Annual servicing of foreign debt (in million EUR)

\begin{tabular}{|c|c|c|c|c|c|c|c|}
\hline Year & $\begin{array}{c}\text { Repayment } \\
\text { and interest }\end{array}$ & GDP & $\begin{array}{c}\text { Foreign } \\
\text { debt }\end{array}$ & $\begin{array}{c}\text { DEBT/ } \\
\text { GDP in } \\
\text { \% }\end{array}$ & $\begin{array}{c}\text { Repayment } \\
\text { and interest } \\
\text { in GDP }\end{array}$ & $\begin{array}{c}\text { Repayment } \\
\text { of the export }\end{array}$ & $\begin{array}{c}\text { The rate of } \\
\text { economic } \\
\text { growth }\end{array}$ \\
\hline 2001 & 103 & 12.821 & 12.609 & 98,3 & 0,8 & 3,7 & 5,6 \\
\hline 2002 & 218 & 16.034 & 10.768 & 672 & 1,4 & 7,1 & 3,9 \\
\hline 2003 & 348 & 17.416 & 10.857 & 62,3 & 2,0 & 9,1 & 2,4 \\
\hline 2004 & 736 & 19.075 & 10.355 & 54,3 & 3,9 & 16,8 & 8,3 \\
\hline 2005 & 945 & 20.358 & 13,964 & 64,8 & 4,6 & 17,9 & 5,6 \\
\hline 2006 & 1,635 & 23,305 & 14,889 & 63,9 & 7,0 & 23,1 & 5,2 \\
\hline 2007 & 2.885 & 28.468 & 17.789 & 62,2 & 9,8 & 33,4 & 6,9 \\
\hline 2008 & 3.453 & 32.668 & 21.088 & 64,6 & 10,8 & 34,5 & 5,4 \\
\hline 2009 & 4.314 & 28.863 & 22.487 & 77,8 & 11,5 & 39,1 & $-3,5$ \\
\hline 2010 & 3.403 & 28.984 & 23.786 & 82,1 & 11,7 & 34,0 & 1,0 \\
\hline 2011 & 4.062 & 31.140 & 24.825 & 77,9 & 12,7 & 35,4 & 1,9 \\
\hline 2012 & 3.858 & 30.074 & 25.721 & 85,6 & 14,5 & 36,4 & $-3,4$ \\
\hline
\end{tabular}


The share of payments to GDP increased from $0.8 \%$ in 2001 and $4.6 \%$ in 2005 to $14.5 \%$ in 2012. The above data show that the outflow of capital in the last two years higher than the overall growth of gross domestic product. Comes to an outflow of capital from the country abroad. Participation in the brain annual increment of gross product in 2008 was about $4 \%$, which increased in 2009 . to over $160 \%$ due to negative rates of GDP growth of minus $3.5 \%$ (Table 10)

The problem is evident in the fact that the debt obligations from year to year increase (from 103 million in 2001 to 3.4 billion in 2008, and 4.3 billion in 2012) So that in recent years is not enough growth domestic product (1-2\%) to be serviced and interest payments on the debt. Liabilities from debt to fully absorb the entire increase in the gross domestic product.

For many loans it received a favourable "grace period", which was to be used for revival of investment and development - to be able to repay the loan growth of the gross domestic product. It is essential, therefore, to be used and what effects the accumulation of income and give foreign loanable funds (whether used for production and investment, and how much goes for other forms of final consumption - personal and budget). Hence it can be seen that the economy is moving in excessive external indebtedness, insolvency and debt crisis. "The noose of debt" is already tightening when the debts increase faster than gross domestic product.

If we want to see the real state debt burden, repayment options (service), the possibilities of new borrowing, encouragement of domestic investment and production of foreign capital and the like. It is necessary to make (and follow) the right of all matrix units that decide to act on the optimum and maximum levels of foreign debt, without having to fly in a debt crisis. Has the economy, such a strategy? Borrowing much from the elements on a case by case basis, no development strategy and borrowing. On the other hand, it is good to be wary of overborrowing policy and "absorption" of foreign capital without jeopardizing economic growth. The basic problem of which the capital is taken, under what conditions and how they are used. One cannot a priori be against foreign capital.

\section{Conclusion}

High public debt, especially if it's on its foreign component does not contribute to economic development and must not be an instrument to underpin economic growth. In regard to this, the government should take measures that contribute to the harmonization of public debt and its servicing capabilities. Otherwise, a short-term policy is qualitatively narrowing of space for future decisions. The use of debt to finance the current deficit or investment projects in the state, and such costs borne by the future, the most negative impact on the flexibility of public finances, which consist of slow economic growth in the coming years.

Height Serbia's public debt is very troubling, no matter what is still - in part - below the level of $60 \%$ of GDP Maastricht criteria specified. The problem is the rate of growth of total public debt in Serbia in recent years, which was higher than the growth rate of GDP, and the unwillingness of the Serbian government to take measures that would lead to fiscal stability and sustainability of public finances. 
Optimum limit of public debt is considered to be the amount of debt that ensures the achievement of desired economic stabilization objectives, financial market development and economic growth, while at the same time not jeopardizing the potential economic and social development. However, the growth of gross domestic product and the maturity of the debt obligations Republic of Serbia suggest that the debt burden increases, debt and weak development of the economy and the power of the state and threatened to open debt crisis, with the emergence of foreign insolvency. In this context, the government should not get into that state of over-indebtedness leads to financial insolvency and instability, which can be achieved so that the rate of growth of public debt in the long term is not greater than the rate of growth of GDP.

\section{Literature}

1. Arestis, P., Sawyer, M. (2004): On Fiscal Policy and Budget Deficits, Journal of Economics, Vol. 1, no. 2, pp. 65-78.

2. Arestis, P., Sawyer, M. (2004): Re-examining Monetary and Fiscal Policy for the 21st Century, Edward Elgar Publishing Inc., Northampton Massachusetts 01060 USA and Louth Lincolnshire, UK. Printed and bound in Great Britain by MPG Books Ltd, Bodmin, Cornwall, pp. 35-38 and 154-189, available at: http://down. cenet.org.cn/upfile/8/200859105050191.pdf

3. Arrau, P. (1990): How Does the Debt Crisis Affect Investment and Growth? International Economics Department, World Bank, available at: www-wds.worldbank.org/servlet/ WDSContentServer/WDSP/IB/1990/04/01/000009265_3960929014431/Rendered/ PDF/multiopage.pdf

4. Balassa, B. (1964): The Purchasing Power Parity Doctrine: A Reappraisal, Journal of Political Economy, Vol. 72, no. 6, pp. 584-596

5. Ball, L., Mankiw, G. (1995): What Do Budget Deficits Do? available at: http:// mostlyeconomics.wordpress.com/2009/06/05/what-do-budget-deficits-do

6. Bernheim, D. B. (1989): A Neoclassical Perspective on Budget Defici, Journal of Economic Perspectives, vol. 3, no. 2, Spring 1989, pp 55-72, available at: www.jstor.org/ discover $/ 10.2307 / 1942669$ ? uid $=2 \&$ uid $=4 \&$ sid $=21101739672263$

7. Blanchard, O. J. (1990): Suggestions for a new set of fiscal indicators, OECD Working Paper no. 79, pp. 10-20, available at: www.oecd.org/tax/public-finance/2002735.pdf

8. Brümmerhoff, D. (2007): Finanzwissenschaft, Auflage, Oldenbourg Wissenschaftsverlag $\mathrm{GmbH}$, München.

9. Buiter, W. (1986): Structural and Stabilization Aspects of Fiscal and Financial Policy in the Dependent Economy, NBER Working Paper no. 2023, available at: www.nber.org/ papers/w2023.pdf

10.Davina, J., Schoeman, N., Van Heerden, J. (2002): Alternative Definitions of the Budget Deficit and its Impact on the Sustainability of Fiscal Policy in South Africa, 
South African Journal of Economics, Vol. 70, no. 3, pp. 251-257, available at: http://onlinelibrary. wiley. com/doi/10.1111/j.1813-6982.2002.tb01303.x/abstract; jsessionid=7CC92DED337590DABF D8C7D6 6F9E0F08.d01t03

11. Đurić, D., Živkov, D., Kolar, S. (2011): Problemi fiskalnih neravnoteža i mogući rizici koji proizilaze u postkriznom period, Ekonomika poljoprivrede, vol. 58, br. 2, str. 299-309.

12. Hubbard, G. (2011): Consequences of Government Deficits and Debt, available at: www. bostonfed.org/economic/conf/monetary-fiscal-topics-2011/papers/ hubbard.pdf

13. Ministarstvo finansija Srbije, Bilten javnih finansija, oktobar 2012, available at: http:// mfp.gov.rs/UserFiles/File/bilten\%20javne\%20finansije/bilten\%20-\%2098\%20-\%20 $\underline{\text { SRP } \% 20 z a \% 20 w e b . p d f}$

14. Ministarstvo javnih finansija Srbije, Bilten javnih finansija, 12/2011, Tabela 1 i 2.

15.NBS, Godišnji izveštaj 2011, jul 2012, available at: www.nbs.rs/internet/latinica/90/90 7 Imonetarna politika 2011.pdf

16. NBS, Izveštaj o inflaciji, februar 2013, tabela A i B.

17. Nikolić, A. (2011): Teskoće funkcionisanja Evropske unije u odsustvu čvršće fiskalne koordinacije, Ekonomija: teorija i praksa, vol. 4, br. 1, str. 154-163.

18. Radcliffe, B. (2009): Can Keynesian Economics Reduce Boom-Bust Cycles, available at: www.investopedia.com/articles/economics/08/keynesian-economics.asp\#axzz1jnZqhnfz

19. Samuelson, P. A. (1964): Theoretical Notes on Trade Problems, the Review of Economics and Statistics, Vol. 46, no. 2, pp. 145-154.

20. Tempelman, H. J. (2005): James M. Buchanan on Public-Debt Finanse, the Independent Review, v. X, n. 2, Winter 2005, pp. 435-449, available at: www.independent.org/pdf/tir/ tir_11_03 06 templeman.pdf

21. Tobin, J. (2001): Its Macroeconomics in Perspective, Cowles Foundation for Research in economics, Yale university Box 208281, New Haven, Connecticut, available at: http:// cowles.econ.yale.edu/P/cd/d13a/d1301.pdf 


\title{
POSLEDICE FISKALNOG DEFICITA I JAVNOG DUGA PO FINANSIRANJE JAVNOG SEKTORA
}

\author{
Aleksandra Tešićc ${ }^{4}$, Dragan Ilićc ${ }^{5}$, Anastazija Tanja Đelićc
}

\begin{abstract}
Rezime
Budžet države je ušao u budžetsku krizu koja će se zaoštriti u sledećim godinama zbog niske stope privrednog rasta, relativno sve manjih prihoda i teškog $i$ sporog smanjivanja javnih rashoda (zbog visoke neelastičnosti naniže). Budžetski deficit i teret javnog sektora su u poslednjim godinama izuzetno povećani u odnosu na finansijsku i razvojnu moć privrede i sektora stanovništva. Preorijentacija na kreditno finansiranje javnih rashoda $i$ budžeta dovodi do ogromnog tereta kamata na dugove i otplata dospelih obaveza. Učešće plaćenih kamata u toku godine u bruto domaćem proizvodu je veće od godišnjeg prirasta bruto proizvoda. Ako se tome dodaju i otplate, tada nastaje faza u kojoj je masa kamata $i$ otplata veća od mase dodatnog godišnjeg bruto proizvoda. Treba posebno istaći da je godišnja dinamika rasta javnih rashoda i prihoda ispod stope nominalnog rasta bruto domaćeg proizvoda i da je sve teže finansiranje javnog sektora, čime je ugroženo njegovo normalno funkcionisanje.
\end{abstract}

Ključne reči: budžetski deficit, investicije, javni dug, potrošnja, ekonomski rast.

4 Vanredni profesor, Univerzitet Privredna akademija, Fakultet za ekonomiju i inženjerski menadžment, Cvećarska 2, 21000 Novi Sad, Telefon: +381 692000 954, E-mail: prof.aleksandra.tesic@gmail.com

5 Docent, Univerzitet Privredna akademija, Fakultet za ekonomiju i inženjerski menadžment, Cvećarska 2, 21000 Novi Sad, Telefon: +381 63539 965, E-mail: prof.dragan.ilic@gmail.com;

6 Docent, Ministarstvo Finansija Republike Srbije, Kneza Miloša 20, 11000 Beograd, Telefon: +381 63295 656, E-mail: tanja.djelic@gmail.com 